\title{
Rusçanın Yabancı Dil Olarak Edinimindeki Zorluklar: Dilbilgisel Cinsiyet Kategorisi
}

\author{
Yrd. Doç. Dr. Leyla Çiğdem Dalkılıç \\ Ankara Üniversitesi DTCF \\ Rus Dili ve Edebiyatı Bölümü \\ dalkilicleyla@hotmail.com
}

\begin{abstract}
Öz
Rusça ve Türkçe farklı dil ailelerine mensup iki dili teşkil etmektedirler. Her iki dili karşılaştırdığımızda bu farklılıklar dilin birçok yapısında kendini göstermektedir. Bu farklılıklardan bir tanesi de dilde sözcüklerin biçimsel ifadesinde görülmektedir. Rusça dilbilgisel cinsiyet kategorisine sahip, adları sınıflara ayıran ve birlikte kullanıldıkları sözcüklerle uyum ilişkisi gerektiren bir dil yapısına sahipken, Türkçe dilbilgisel cinsiyete sahip olmayan bir dildir. Rus dilinde dilbilgisel bir kategori olarak bulunan cinsiyet kategorisi sayı, sıfat, zamir çekimleri başta olmak üzere dilin tüm kısımlarını etkilemektedir. Bunun yanı sıra, söz konusu kategorinin Rus dilinde çeşitli ifade araçlarına sahip olması ve verilen genel kuralların dışında oldukça fazla istisnai kullanımı olması nedeni ile bu konu, Rusçayı yabancı bir dil olarak öğrenen Türk öğrencilerin karşılaştığı bir zorluk olarak ortaya çıkmaktadır. Bu çalışmada, Rus dilinin dilbilgisel cinsiyet özellikleri ele alınmakta ve dilde ayrı bir kategori olarak ele alınan dilin bu kısmının yabancı bir dil olarak edimindeki zorluklarına değinilmektedir. Dil edinimindeki zorlukları ortaya koymak amacıyla Rusça ve Türkçedeki cinsiyet kavramının dillerde nasıl kendisini gösterdiği ve diller arasındaki farklar ile benzerlikler de ele alınmaktadır. Bu çerçevede, söz konusu kategorinin morfolojik, sözdizimsel, sözcüksel-anlamsal ve sözcüksel-türevsel olmak üzere dört temel araçla dilde nasıl ifade edildiği ve eril, dişil ve nötr olmak üzere üç cinse sahip olan Rus dilinde sözcüklerin cinslerini belirleme sürecinde yaşanan zorluklar örneklendirmelerle ortaya konulmuştur.
\end{abstract}

Anahtar Kelimeler: Rusça, Türkçe, dil bilgisel cinsiyet, edinim zorlukları.

\section{Difficulties Faced in the Learning of Russian as a Foreign Language: Grammatical Gender Category}

\footnotetext{
Abstract

The Russian and Turkish languages belong to different linguistic families. When we compare both languages, their differences show themselves in many constructs of language. One of these differences is the formal expression of words. The Russian language has the category of gender which separates words into classes and requires a relationship of harmony among words that are used together. On the contrary, the Turkish language does not have grammatical gender. The gender category, which acts as a grammatical category in 
Russian, affects all parts of the language, especially number, adjectives, and pronoun conjugations. In addition, it presents a challenge for Turkish students who learn Russian as a foreign language, because of the fact that this category has various means of expression in the Russian language and possesses a lot of exceptional uses apart from the given general uses. The gender linguistic features of Russian and the difficulties in the acquisition of this category which exists as a separate category in the language are discussed in this study. In order to demonstrate the difficulties of language acquisition, how the category of gender shows itself in Russian and Turkish as well as the similarities and differences between languages on this subject are discussed. In this context it is shown how this category in Russian is expressed with morphological, syntactic, lexical-semantic and lexical-word derivation methods. Further, the difficulties in the process of putting up the gender of words in Russian, which has three genuses (masculine, feminine and neuter), are mentioned, with examples.

Keywords: Russian, Turkish, grammatical gender, learning difficulties. 


\section{GíRIŞ}

Batı dillerindeki karşılığının kaynağı Latincedeki 'genus' kelimesinden gelen cinsiyet kavramı, bugün algılandığından farklı olarak gerçek cinsiyetten çok, 'tür' anlamına sahiptir. Birçok dilde görülebilen dilbilgisel bir kategori olan cinsiyet "adlarla ilgilidir ve varliklara ad olan sözcüklerin ayrı biçim sımılarına ait olduğunu gösterir" (Uzun 2004: 110-111). Dillerdeki cinsiyet kavramı, adları sınıflara ayıran ve birlikte kullanıldıkları sözcüklerle uyum ilişkisi gerektiren bir kategoridir. Dilbilgisel cinsiyet kategorisine sahip dillerde canl1-cansız şeklinde sınıflandırılan sözcükler genel olarak eril-dişil-yansız cinsiyet türleri olmak üzere ayrılarak insan-hayvan-nesne karşıtlıklarını kodlayan sistemler bütünü olarak karşımıza çıkarlar.

Cinsiyet kavramı ile ilgili çalışmalara bakacak olursak (M.H. Atlı, F.Ö. Dağabakan, C. Kerimoğlu, R. Şakar) dillerde cinsiyet kavramı genel olarak biyolojik ve dilbilgisel cinsiyet olmak üzere iki açıdan ele alınmaktadır. Rus dilinde yapısal bir özellik gösteren dilbilgisel cinsiyet, Rusçada önemli bir yere sahiptir. Dil öğelerinin diğer dil öğeleriyle uyumu ve dilbilgisel cinsiyet ile tanımları, bazı istisnai durumlar haricinde, genel olarak bu kurala bağlıdır. Rusçada dilbilgisel bir kategori olarak bulunan cinsiyet kategorisi sayılar, sıfatlar, zamirler, ismin hal çekimleri, geçmiş zaman ekleri başta olmak üzere dilin tüm kısımlarını etkilemektedir. Rus dilinde tekil haldeki sözcükler eril, dişi (dişil) ve (yansız) nötr olmak üzere üç cinse aittir. Bu üç ayrı cinsin dile yansımaları ise farklı şekillerde meydana gelebilmektedir. Diğer bir deyişle, Rus dilinde cinsiyet kategorisinin ifadesi sırasında çeşitli araçlardan yararlanılmaktadır. Bu araçları dört temel grupta inceleyebiliriz. Bunlar sırasıyla morfolojik araçlar, sözdizimsel araçlar, sözcüksel-anlamsal, sözcüksel-türevsel olmak üzere karşımıza çıkmaktadırlar. Morfolojik araçlar dildeki morfemlerin belirli kurallar çerçevesinde kullanılması durumudur. Sözdizimsel araçlar, kelimenin sonundaki morfeme (ya da eke) göre diğer sözcük türlerinin belirtilen isimle belirli kılınması durumudur. Sözcüksel-anlamsal araçlar, sözcügün biçimsel yapısından farklı olarak bir kelimenin cinsinin sözcüğün anlamından çıkartıldığı durumlardır. Son olarak da sözcüksel-türevsel araçlar, bir sözcüğün dildeki belirli isim yapım eklerinin cinslere göre sahip oldukları eklerle belirlenmesi durumudur. Bu bakımdan, Rus dilindeki cinsiyet kategorisi yalnızca dildeki sözcüklerin doğru kullanılması ya da fiil ve ad çekimlerinin gerektiği şekilde yerine getirilmesi açısından değil, dilde sözdizimi açısından dil kurallarına uygun tümce türlerinin oluşturulması için de önemlidir. Bu açıklamadan da anlaşılabileceği üzere Rus dilinde cinsiyet kategorisi diğer ulamları etkileyen ve dil öğrenim sürecini zorlaştırıcı bir etmen olarak karşımıza çıkmaktadır. Söz konusu çalışma ile amaç Rus diline hakim olma sürecinde önemli bir yere sahip olan bu ulamın edinimi esnasında Rusçayı yabancı bir dil olarak öğrenen Türk öğrencilerinin karşılaştıkları zorlukları ortaya koyarak bu konuya ilişkin oluşturulabilecek olası eğitimsel öğretici metotların geliştirilmesine dikkat çekmek, sistemsel herhangi bir metodun oluşturulup oluşturulamayacağını anlamaya çalışmaktır. Türk öğrencilerinin Rusçanın bu kategorisini öğrenmede yaşadıkları belli başlı zorlukların çalışmada aktarılmasının ileride oluşturulabilecek eğitim metotlarının gelişimi için yararlı olabileceği düşünülmektedir. Bu zorlukların sistemsel bir şekilde ortaya konması Rusça derslerinde öğrencilerin hatalarından yola çıkılarak sıralanmış ve konuya ilişkin Rus dilbiliminde kimi öncü çalışmalardan yararlanılmıştır.

Öncelikle, Rus dilindeki cinsiyet kategorisinin dildeki yansımalarında kullanılan çoklu ifade araçların ne şekilde ortaya çıktıklarını sırasıyla incelemek Rus dilindeki cinsiyet kategorisinin öğrenilmesindeki zorluğu gözler önüne sermek bakımından yararlı olacaktır.

SEFAD, 2017 (38): 279-298 


\section{Morfolojik Araçlar}

Rus dilinde kelimelerin cinslerinin belirlenmesinde morfolojik araçlar birinci sırada yer almaktadır. Genel olarak dilde yalın halde bulunan ve sonu $-a$ ya da $-я$ harfleri ile biten kelimelerin dişi cinse (книга, лампа, земля, вищня); dilde yalın halde bulunan ve sonu sessiz harfle biten, bir bakıma hiçbir çekim eki almayan sözcüklerin eril cinse (дом, cad, nu^om, шахтёр); dilde yalın halde bulunan ve sonu $-o,-e$ ve - ё (окно, дело, море, поле, копьё) ile biten kelimelerin ise nötr cinse ait oldukları kabul edilir. Dildeki cinsiyet kategorisine ilişkin verilen bu kural çerçevesinde ilk etapta bu kategorinin öğrenimi kolay sayılabilmektedir. Ancak istisnai durumların çokluğu ve dildeki cinsiyet kategorisinin bu genel kural dışında başka göstergelerle de ifade edilebilmesi bu kategorinin öğrenimini zorlaştırmaktadır. Bunlardan bir tanesi, yumuşatma işareti ile biten " $b$ " sözcükler için geçerlidir. Sonunda yumuşatma işareti barındıran sözcükler dişi cinse (жизнь [hayat], тень [gölge]) ait olabildikleri gibi eril cinse de (словарь [sӧzlük], календарь [takvim]) ait olabilmektedirler. Bu durum, öğrencilerin kelimelerin cinslerini belirlemede yaşadığı zorluklardan bir tanesini oluşturmaktadır. Rusçayı öğrenenler, biçim açısından hiçbir şekilde sözcüğün cinsini ayırt edemeyeceklerinden ötürü yumuşatma işareti ile biten tüm kelimelerin cinslerini ezbere bilmek diğer bir ifadeyle ezberlemek durumunda kalmaktadırlar. Rus dilinde sözcüklerin cinslerini belirlemeye yönelik zorluklar yalnızca bununla sınırlı kalmamaktadır. Nötr cinse ait kelimeler yukarıda belirtilen morfolojik araçların yanı sıra dilde dokuz adet kelimeyi karşılayan (бремя, вымя, время, знамя, пламя, племя, семя, стремя, темя) ve -мя harfler ile sona eren sözcükleri de kapsamaktadır. Bu bağlamda, Rus dilinde kelimelerin cinslerinin morfolojik olarak ifadesi karmaşık bir şekilde gerçekleşmektedir. Bu karmaşık durum, özellikle de ileride ayrıntılı bir şekilde ele alacağımız, sözcük anlamlarından yola çıkılarak cinsleri belirlenen kelimelerde karşımıza çıkmaktadır. Rus dilinin sahip olduğu genel kuralların dışında çıkması ve birçok istisnai durumu içinde barındırması dildeki cinsiyet kategorisinin öğrenilmesinde zorluk yaratan temel etmeni oluşturmaktadır. Bunun yanı sıra, dilde hem eril hem de dişi cinse ait kelimelerde görülen (корабль/gemi-eril cins; мъıиъ/faredişi cins, deнъ/gün- dişi cins, ^юбовъ/aşk/sevgi- dişi cins vb.) yumuşatma işaretine sahip tüm kelimelerin ezberlenerek öğrenilmesi zorunluluğu, Rus dilinin yabancı bir dil olarak öğrenimini ve bu dilin sözcük türlerinin doğru kullanımını güçleştirmektedir. Türk öğrencilerinin sonu yumuşatma harfi ile biten kelimelerin cinslerini belirlemede yaşadığı zorluklara örnek olarak sınavda kendilerine yöneltilen sorulardan aşağıdaki şu iki örnek verilebilir:

Она смотрела на сына с (любовь)

Она уезжает из Москвы с (грусть)

Cümlelerde verilen "любовь" "грусть" kelimeleri biçim ve cins özellikleri açısından aynı olmasına rağmen, birinci kelime ikinci kelimeye oranla daha fazla bilindiğinden ötürü birinci kelime doğru bir şekilde dişi cins olarak belirlenerek çekimlenmiş, ikinci sözcük ise, yukarıda bahsedilen mevcut zorluktan ötürü, eril cinse ait bir kelime gibi saptanmıştır. Buna göre, on öğrenciden üçü "грyсmъ" sözcügünü dişi cins kurallarma uygun olarak çekimlerken, on öğrenciden beşi sözcüğün cinsine ilişkin tercihlerini eril cinsten yana kullanmıştır. On öğrenciden ikisi ise, sözcügün hangi cinse ait olduğunu belirleyemedikleri için soruyu yanıtsız bırakmışlardır. Sözcüğün çekimini doğru yapan öğrenciler sadece 
sözcüğün cinsini bildikleri için yanılmadıklarını ifade ederken, yanlış yapan öğrenciler ise, sözcüğün cinsini eril olarak düşündükleri için ismin eril cins çekimini tercih etmişlerdir.

Buradan yola çıarak sonu yumuşatma işareti ile biten kelimelerin cinsiyetlerinin belirlenmesi esnasında öğrencilerin çağrışımsal cinsiyet kavramından yararlanıp yararlanmadıklarını anlamak ve bunun, sözcüğün cinsiyetini belirlemede öğrencilere ne kadar yararlı olup olmadığını anlamak üzere on iki kişiden oluşan küçük bir grup öğrenciye Türkçe anlamları ile birlikte sonu yumuşatma işareti ile biten 47 'si eril cinse, 57'si dişi cinse ait olmak üzere 104 kelime sunulmuş, kelimelerin dişi ya da eril olmak üzere cinslerinin belirlenmesi istemiştir. Her bir kelime için açıklama almak mümkün olmamakla birlikte öğrenciler belli başlı bazı kelimelere ilişkin bir takım yorumlarda bulunmuştur. Öğrenciler sonu yumuşak harfle biten kelimelerin cinslerini 1) telaffuzlarına göre belirlemişlerdir: okunuşu öğrenciye kaba gelen sözcükler eril, telaffuzu yumuşak gelenler ise dişi olarak seçilmiştir. 2) автомобиль, контроль gibi kelimelerin yabancı kökenli oldukları için eril cins olarak belirlendikleri ifade edilmiştir. 3) küfür (брань - dişi), kütük (nень - eril), iskele (пристань - dişi), çanta (nортфель - eril), dirsek (^oкоть - eril) gibi erkeklerin çalışma, ilgi ve kullanım alanlarına giren benzeri kelimeler erkeklerle ilişkilendirilerek eril cinse ait olarak seçilmişlerdir. 4) doğa olaylarının hemen hemen hepsi dişi olarak belirlenmiştir. 5) "kötü anlama" sahip olduğu ifade edilen kelimeler de dişi olarak belirlenmiştir ve ilginçtir ki hepsinin cins seçimi doğru çıkmıştır, örneğin, acı (боль - kötü anlam), küfür (брань - kötü anlam), yanık (zарь - kötü anlam), ölüm (гибель - kötü anlam), tembellik (^ень - kötü anlam), kir (грязь - kötü anlam), yarık (щ̧ель - kötü anlam) gibi. Daha öncede ifade edildiği üzere, öğrenciler sonu yumuşatma işareti ile biten kelimelerin çoğunun cinsiyetlerini belirlemede zorluk yaşamışlar, bu nedenle birçok kelime boş bırakılmış, ancak yukarıda kısa bir biçimde ifade ettiğimiz sebepleri sunabilmişlerdir. Sonuçlar incelendiğinde, dağıtılan kağıtlarda dişi cine ait kelimeler fazla olmasına rağmen, öğrenciler çoğu kelimenin cinsini eril olarak seçmiştir (tablo 1).

\begin{tabular}{|l|l|l|l|l|l|l|}
\hline & $\begin{array}{l}\text { Soru } \\
\text { sayıs1 }\end{array}$ & $\begin{array}{l}\text { Eril kelime } \\
\text { sayıs1 }\end{array}$ & $\begin{array}{l}\text { Dişi kelime } \\
\text { sayıs1 }\end{array}$ & $\begin{array}{l}\text { Eril } \\
\text { tercihi }\end{array}$ & $\begin{array}{l}\text { Dişi } \\
\text { tercihi }\end{array}$ & Boş \\
\hline Öğrenci 1 & 104 & 47 & 57 & 47 & 4 & 53 \\
\hline Öğrenci 2 & 104 & 47 & 57 & 53 & 34 & 17 \\
\hline Öğrenci 3 & 104 & 47 & 57 & 60 & 37 & 7 \\
\hline Öğrenci 4 & 104 & 47 & 57 & 16 & 40 & 48 \\
\hline Öğrenci 5 & 104 & 47 & 57 & 44 & 14 & 46 \\
\hline Öğrenci 6 & 104 & 47 & 57 & 73 & 31 & 0 \\
\hline Ö̆ğrenci 7 & 104 & 47 & 57 & 56 & 38 & 10 \\
\hline Öğrenci 8 & 104 & 47 & 57 & 87 & 5 & 12 \\
\hline Öğrenci 9 & 104 & 47 & 57 & 66 & 34 & 4 \\
\hline Öğrenci 10 & 104 & 47 & 57 & 97 & 7 & 0 \\
\hline Öğrenci 11 & 104 & 47 & 57 & 56 & 48 & 0 \\
\hline Ö̆ğrenci 12 & 104 & 47 & 57 & 16 & 21 & 67 \\
\hline
\end{tabular}

Tablo 1 
Böylece Türk öğrencileri için erillik çağrışımının yüksekliği bir kez daha görülebilmektedir. Bu da dillerin insan zihninde 'erkek' egemen araçlar olarak yer ettiği şeklindeki feminist dilbilim anlayışının yaklaşımıyla uyumlu bir netice ortaya koymuş olmaktadır (Kerimoğlu-Doğan 2015: 155). Sonuç olarak, sonu yumuşatma harfi ile biten kelimelerin belirlenmesinde belirli bir kriter oluşturulamadığı gibi her bir kişi için çağrışımlar sübjektif bir özellik sergileyebildiğinden çağrışımsal yaklaşım kelimelerin cinslerinin belirlenmesinde başvurulabilecek yararlı bir yöntem olma özelliğini kaybetmektedir.

Sonu yumuşatma işareti ile biten kelimelerin öğretiminde bizce sunulabilecek birkaç metot bulunmaktadır. Bunlardan ilki uygun kaynak seçimi ve yardımcı görsel kaynakların oluşturulabilmesidir. İkincisi ise sonu yumuşatma işareti ile biten sözcüklerin öğelerin kullanımı ile söz konusu dil birimlerinin öğretilmesidir. Rusçada sonu yumuşatma işareti ile biten kelimelerin kullanımlarına ilişkin oldukça az kaynak bulunmaktadır. Konuya ilişkin söz konusu teorik bilgi verildikten sonra, bu sözcüklerin çalışma aşamasında S. Ramazanova vd. tarafından hazırlanmış olan "Rusça-Türkçe Yumuşatma İşaretiyle Biten İsim Sözlüğü" temel kaynaklardan bir tanesi olarak kullanılabilir. Belirtilen sözlükte yapılan çalışmalar sonucunda eril cinse ait 662, dişi cinse ait 2251 adet olmak üzere toplam 2913 kelimeyi bünyesinde barındıran sözlük, kelimelerin anlamlarını içermesi ve sözcüklerin ismin hallerine göre uğradığı çekim değişimlerini de göstermesi açısından önemlidir (Ramazanova vd. 2016: 5-6). Sözlüklerin yanında, sonu yumuşatma işareti ile biten kelimelerin öğrenimi zorlu olduğundan, kaynak çeşitlendirmesi farklı şekillerde de gerçekleştirilebilir. Söz gelimi, kadın ve erkek figürlerinin yer alacağı, açıklamaları ile birlikte sadece görsel unsurların yer alacağı resimli bir ders kitabı oluşturulabileceği gibi, yine dişi ve eril cinse ait farklı görsellerin bulunacağı ders kitabında varlıklar hem ait oldukları nesneyi aktarabilecek şekilde sunulabilir hem de varlıklar, cinsine göre, dişi ve erkek cinse atfedilen mavi ve pembe renkte resmedilebilirler. Böyle bir yöntem öğrencilerin görsel hafızlarının da eğitim sürecine dahil edilerek öğrenimin hızlı ve etkili bir şekilde gerçekleştirilebilmesine yardımcı olacaktır. İkinci bir metot ise, sonu yumuşatma işaretine sahip kelimelerin sahip oldukları sıfat, zamir gibi belirteçlerle birlikte öğretilmesidir: мой корабль, чёрный портфель, красивая пристань, ужаснал гибель vs. Böylelikle öğrenci hem sözcüklerin cinslerini daha kolay aklında tutabilecek hem de kelimeler arası eşdizimlilik özelliklerini öğrenmiş olacaktır.

Yukarıda hem yumuşatma işareti hem de sonu - $\mathcal{M} \Omega$ ile biten sözcüklerin cinslerinin belirlenmesine ilişkin sıkıntılar özellikle ad çekimleri sırasında görülmektedir. Sözcüğün hangi cinse ait olduğunu belirleyemeyen öğrenci ya da kelimeleri bilmediği veya ezberinde tutamadığı için sonu - $\mathcal{M}$ Я ile biten nötr cinse ait sözcükleri dişi cinse aitmiş gibi kabul edebilmekte ve ad durum çekimlerini yanlış gerçekleştirmektedir.

Rus dilinde cinslerin morfolojik araçlar yardımıyla öğrenilmesini güç kılan bir diğer durum da yabancı kökenli olarak kabul edilen ve dilde hiçbir şekilde çekime uğramayan sözcüklerin kullanımında görülmektedir. Yabancı dillerden Rusçaya giren ve cansız varlıklara işaret eden kelimelerin genel olarak her ne kadar da nötr cinse ait olduğu yönünde belirlemeler yapilsa da (Kuzmina 2014: 28, Milanova 2011: 12, Novikov vd. 2003: 393) yine bu duruma ilişkin istisnalar mevcuttur. Örneğin, кино (sinema-nötr cins), кофе (kahve-eril cins), Миссисипи (Missisipi nehri-dişi cins), maкcu (taksi-nötr cins), интервъю ( röportaj - nötr cins), Сочu (Soçi şehri - eril cins) gibi kelimelerin cinslerini sahip oldukları son eklere bakarak anlamak mümkün değildir. Bunun yanı sıra "tüm yabancı kökenli sözcükler ya da çoğunluğu nötr cinse aittir" şeklindeki açıklama da yanıltıcı olabilmekte ve eksik 
kalmaktadır. Dilde birçok yabancı kökenli kelime olduğu gibi bunların hepsi birbirinden çeşitli son seslere sahip olmakla birlikte her biri farklı cinslere aittir. Yabancı kökenli sözcüklerin dilde hangi cinse ait olduklarının belirlenmesinde yardımcı olabilecek ve bu süreci kolaylaştıracak bazı yöntemler vardır. Sonuna farklı ekler alan yabancı kökenli yer adlarının cinsleri işaret ettikleri varlığa göre belirlenebilir. Örneğin, Мuсcucunu (Missisipi nehri) nehir olduğu ve 'nehir' (река) sözcüğü dilde dişi cinse ait olduğu için, sözcük doğrudan dişi cinse ait olarak kabul edilir, yine aynı şekilde Сoчu (Soçi şehri) şehir olduğu ve 'şehir' (2ород) sözcügüu dilde eril cinse ait olduğu için kelimenin eril cinse ait olduğu kabul edilir. Ancak bu yöntem her zaman her durum için işe yaramayabilir. Özellikle de canlı varlıklara işaret eden ve sonu farklı morfolojik araçlarla biten sözcüklerin cinslerinin belirlenmesi daha zordur. Kimi durumlarda sözcüğün işaret ettiği kavrama bakılarak sözcüğün cinsi belirlenebilir: ^edu (leydi-dişi cins), фpay (hanımefendi - dişi) месьe ya da м⿻ьё (mösyö - eril cins) gibi. Ancak kimi durumlarda özellikle de sözcüklerin hem erkek hem de dişi cins için kullanılabilmesi Rusçayı yabancı dil olarak öğrenenler için hafızalarında belirli bir şema oturtmaları konusunda güçlük yaratabilir. Örneğin kanguru anlamına gelen кенгуру sözcüğü eril cinse ait bir sözcük olmasına rağmen, hem erkek hem de dişi cins için kullanılabilir. Aynı durum маэстро (maestro), буржуa (burjuva) ve ammaue (ateşe) kelimeleri için de geçerlidir. Bunlar cins olarak eril olmalarına karşın yapısal olarak hem farklı morfolojik araçlara sahiptir hem de kadın ve erkek için de kullanılabilirler. Yabancı kökenli olup da ad çekimine uğramayan bu ve benzeri sözcüklerin dildeki kullanımları çok daha zorlu süreçleri beraberinde getirmektedir. Bu durumuna ilişkin diğer örnekler ve kullanım özellikleri ilerleyen kısımlarda ayrıntısıyla ele alınacaktır.

Yabancı kökenli olup da ad çekimine uğramayan sözcüklerin dile yerleşmesi ve yaygınlaşması çağdaş Rus dilinde bazı ikilemleri de beraberinde getirmiştir. Bu ikilemler özellikle de ismi niteleyen, belirten sıfat ve zamir çekimlerinde yaşanmaktadır. Buna göre, yabancı kökenli kelimelerin dildeki cinslerinin belirlenmesi ve çekimlerinin buna göre yapılması ya, yukarıda ele alındığı üzere, dilde denk geldikleri varlıkların anlamlarından yola çıkılarak belirlenmekte ve kelimenin etkilediği diğer sözcük türlerinin cümle içerisindeki çekim özellikleri bu doğrultuda gerçekleşmektedir ya da kelime yabancı kökenli olduğu için nötr cinse ait olduğu kabul edilmekte ve bu yönde dilde çekime uğramaktadır. Örneğin, tropik bir meyveye işarete eden ve Rusçaya yabancı kökenli bir sözcük olarak giren манго (mango) kelimesinin cinsi dilde iki şekilde belirlenebilmektedir:

1) Yabancı kökenli olduğu için nötr cins olarak mango: Вкусное манго (lezzetli mango) ya da;

2) Meyve olduğu ve meyve "Фрукm" sözcü̆̆̈̈ dilde eril cins olarak kabul edildiği için kelime eril cinse aitmiş gibi belirlenebilir: вкусный манго

Yine aynı şekilde uуннами (tsunami) kelimesi yabancı dillerden Rusçaya girdiği için nötr cins olarak belirlenebilir ya da bir deniz dalgası olarak dilde dişi cinse ait olan волна kelimesi ile eşleştirilerek dişi cinste kullanılabilir:

1) Yabancı kökenli ve nötr cins olarak: Цунами возникло;

2) Волна "dalga" kelimesinden dişi cins olarak: Цунами возникла (Tsunami meydana geldi). 
Bu ve benzeri sözcüklerin kullanımındaki cins özelliği, sözcükten önce kullanılan sıfat, zamir gibi dil öğelerinin sahip oldukları cins çekim ekleri veya eylem geçmiş zamanda belirtiliyorsa geçmiş zamanın cinslere göre değişiklik gösteren çekim ekleri ile belirli kılınmaktadır: щирокое авеню / широкая авеню (geniş sokak: nötr cinste ifadesil ya da geniş sokak: dişi cinse ait olan "yлицุa" "sokak" kelimesinden ötürü dişi cinste ifadesi). Yine yabacı kökenli olan ve dilde kullanılan bazı kelimeler de nötr cins olarak kabul edilmelerine rağmen dilin diğer kısımlarıyla birlikte söylemde çoğul olarak ifade edilmeleri tercih edilmektedir: вкусное yerine вкусные суши (lezzetli suşiler), очередное уerine очередные ралли (bir sonraki ralli yarışları), опущенное yerine опущенные жалюзи (indirilmiş perdeler) gibi.

Yine dilde cinsine yönelik tartışma konusu olan sözcükler vardır. Örneğin, кино (sinema) ve кофе (kahve) kelimeleri nötr cins için kabul edilen son eklere sahip olmalarına rağmen 'sinema' sözcüğü nötr cinse, 'kahve' sözcüğü ise eril cinse ait bir kelime olarak kabul edilir. Buna karşılık, çağdaş dilbilimciler kahve sözcügünün nötr cins olarak da dilde kullanıldığını, bu nedenle de her iki cinse de sahip olabileceği görüşünü savunmaktadırlar (ROS: 2002).

\section{Sözdizimsel Araçlar}

Dilde sözcükler arasındaki cinsiyet özelliklerini belirlemede kullanılan bir diğer araç ise sözdizimsel araçlardır. Cinsiyet kavramının dilde sözdizimsel araçlarla ifadesi, sözcüğe bağlı olarak metin içerisindeki diğer yapıları da etkilemektedir. Bu da Rusçadaki cinsiyet kategorisinin öğrenilmesinde dil edinimini zorlaştıran bir başka etken olarak karşımıza çıkmaktadır. Örneğin, özne durumundaki kelime, varsa sıfatın, fiil çekiminin ve zamirin cinsini etkileyerek meydana gelmektedir. Çekime uğrayan tüm yapıların cins uyumu göstermesi zorunludur. Örneğin, dişi cinse ait bir sözcüğün kullanımı dilin diğer tüm sözcük türlerini çekim açısından etkileyecektir: Наша (zamir) / маленькая (sıfat) / собака (isim)/ играла (yӥklem)/ с соседской собакой (belirleyici).

Sözdizimsel araçların kullanımı özellikle de ortak cins veya biyolojik özelliklerinden, sözcük anlamından yola çıkarak cinsini belirlediğimiz kelimelerin ifadesinde önemli bir rol oynamaktadır. Yukarıda sıraladığımız eril-dişi-nötr cinslerinin dışında dilde bir de ortak cins olarak adlandırılan ve hem eril hem de dişi cinse ait varlıklar için kullanılabilen sözcükler bulunmaktadır: калека (sakat), обжора (obur),cupoma (öksüz) vb. Görünüşte dişi cinsin morfolojik araç ifadesine sahip olan bu sözcüklerin dişi mi yoksa eril bir cinse mi ait varlıkları ifade ettikleri, cümle içerisinde konuşan kişinin söylemlerinden yola çıkarak belirlenmektedir. Ortak cinse ait kelimelerin belirlenmesinde yardımcı işleve sahip diğer araçlar ise eril ya da dişi olmak üzere gerekli cins çekim ekleriyle ifade edilen sıfatlar, zamirler ile fiilin geçmiş zaman çekim ekleridir. İsimden önce gelen zamir veya sıfat gibi sözcük türleri ile eylemin cinsini belirli kılan çekim ekleri sözcügün cinsinin ortaya konmasında önemli bir role sahiptir: Öyle pisboğaz ki! = такой обжора! (eril cins için) / maкая обжора! (dişi cins için). Bu ve benzeri söylemlerde sözcüğün cinsi farklılık gösterse de ifade edilen sözcük anlamı değişmemektedir.

Sözdizimsel araçların bir diğer önemi biyolojik cinsiyete sahip sözcüklerin cinslerinin doğru bir biçimde ortaya konmasında kendini göstermektedir. Örneğin, dilde dişi cinse ait kelimelerin bir morfolojik aracı olarak karşımıza çıkan, sonu - a ya da - $я$ harfi ile biten dildeki дедушка (dede), дядя (amca/dayl), юноша (genç), nапа (baba) gibi bazı kelimelerin sözdizimsel açıdan kullanımı Rusçayı özellikle de ilk etapta öğrenenler için kafa karıştırıcı olabilmektedir. Öğrenciler, kelimenin eril cinse ait bir varlığı karşıladığını bilmelerine rağmen kelimeyi niteleyen dilin diğer öğelerini istem dişı olarak dişi cins gibi 
çekimleyebilmekte, "sözcük biçimsel olarak dişi cins özelliklerini gösterse de eril cins gibi çekime uğrar" kuralını yok sayabilmektedirler:

Моя папа пришла с работы

(Babam işten geldi) - olması gereken:

Мой папа прищёл с работы

Ortak cinse ait kelimeler ile biyolojik cinsiyet kavramı içerisinde ele alınan sözcüklerin cinslerinin belirlenip ortaya konması ancak sözdizimsel araçların yardımıyla mümkün olabilmektedir. Bu sözcüklerin de dişi cinse ait morfolojik araçlarla ifade edilmeleri Rusçayı yabancı bir dil olarak öğrenenler için dildeki sözcüklerin cinslerinin anlaşılması ve belirlenmesine ilişkin bir başka zorluğu da beraberinde getirmektedir.

\section{Sözcüksel-Anlamsal Araçlar}

Dildeki sözcüklerin cinslerinin morfolojik ve sözdizimsel araçlarla belirlenebilmesinin yanı sıra kelimeler, dilde sözcüksel-anlamsal olarak yani sözcük anlamlarından yola çıkılarak da belirlenebilmektedir. Örneğin, миamb (anne) - omeu (baba), бpam (erkek kardeş) - cecmpa (kız kardeş), nетух (horoz) - курица (tavuk), бык (boğa) - корова (inek) gibi kelimelerin sözcük anlamlarından yola çıkarak cinsiyet belirlemesi yapılabileceği gibi burada verilen örnekler morfolojik biçim açısından da kelimelerin cinslerinin belirlenmesinde kolaylık sağlamaktadır. Ne var ki morfolojik olarak dişi cins ekine sahip olan ancak anlam açısından eril cinse ait kelimelerin cins aitlikleri de yalnızca anlamlarından yola çıkarak belirlenebilmektedir. Bu kelimelere örnek olarak папа (baba), дядя (amca/dayı), дедушка (dede), юноша (genç erkek çоcuk) kelimeleri verilebilir. Bunların en büyük özellikleri, az önce de belirttiğimiz gibi, dişi cins çekim ekine sahip olmalarına rağmen eril cinse ait varlıklara işaret etmeleridir. Bunun dışında, dişi cins çekim ekine sahip olmalarından ötürü dilde bu sözcükler ismin tüm hallerinde diğer dişi cinse ait sözcükler için geçerli olan kural çerçevesinde çekime uğrarlar. Bu sözcüklerle birlikte kullanılan sıfat, zamir, fiil gibi cins kategorisinin morfolojik olarak ortaya çıktığ yapılar, kelimenin eril cinse ait olduğunun belirli kılınabilmesi için eril cinste ifade edilirler. Bu ve benzeri sözcükler anlamdan bağımsız olarak yalnızca biçimsel özelliğin kelimenin cinsiyetinin belirlenmesinde yardımcı olamadığı durumlarda görülmektedir. Bu durumda, bir sözcüğün cinsiyetinin belirlenmesinde biyolojik cinsiyet kavramı devreye girmektedir. Bu bağlamda, sözcügün işaret ettiği varlık veya olgu dilbilgisel cinsiyetin belirlenmesinde önem taşımaktadır.

Biyolojik cinsiyete sahip kelimelerin dışında, kelimelerin eril ve dişi cins ayrımında şu noktalara dikkat etmek gerekir: Eril cinse ait kelimeler cinsiyeti erkek olan kelimeleri ifade etmesinin yanı sıra kişinin sosyal ve profesyonel alanına yönelik genel anlamları içeren meslek adlarını da içermektedir. Meslek adları çoğunlukla dilde eril cinse ait olmalarına rağmen hem kadın hem de erkekler için ifade edilebilir: он-хороший врач / она - хороший врач (o kadın/erkek iyi bir doktordur). Bu ve benzeri cümlelerdeki cins ayrımı eril ya da dişi olarak kullanılan işaret zamiri ile yapılmaktadır. Çoğunlukla eril cinse ait bazı meslek adları da dişi cinse ait çekim eklerine sahip olmalarına rağmen ortak cinse ait kabul edilirler: колиега (iş arkadaşı), судья (hakim/ hakem), глава (başkan, müdür, yönetici, baştaki kişi anlamlarında) gibi. Her iki durumda da dildeki cinsiyet ayrımını başta kullanılan eril veya dişi cinse ait kişi zamirleri veya kişilere ait isimlerle belirleriz. Ancak dişi cinse ait meslek isimlerinin çekimi daha önce de belirtildiği gibi dilde her zaman ister erkek ister kadın belirtilsin dişi cins çekim eklerine sahip olacaktır: 
Вчера он видел своего колиегу (Dün erkek iş arkadaşını gördü)

Вчера он видел свою коллегу (Dün kadın iş arkadaşını gördü)

Aynı çekim ekine sahip kelimelerin ifade ettikleri biyolojik cinsiyet ayrımı sözcükten önce kullanılan zamir veya sıfatın dişi ya da eril çekim eki almasıyla belirlenir. Bunun yanı sıra dilde eril cins olarak kabul edilen ancak hem kadınlar hem de erkekler için kullanılabilecek kelime grupları mevcuttur. Bunlar içerisinde hem meslek adlarını barındırabildikleri gibi genel sözcükleri de kapsayabilirler: evlatlık (приёмьии), ikiz (близнец), pedagog (педагог), arkeolog (археолог), filolog (филолог), yazar (автор), boksör (боксёр), hokey оуипсияи (хоккеист), antrenör (тренер), halterci (итангист), с̧ауlak (новичок), уауа (переход) vs.

Son olarak, hayvan adlarından bazıları varlıkları hem eril hem de dişi cinste ifade edilebilme özelliğine sahip olabildikleri gibi (кот-кошка/ kedi; конь-лошадь/at; козёл - коза /

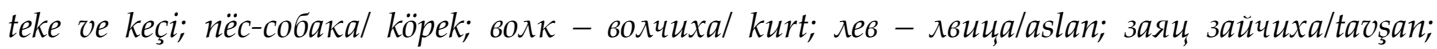
медведь медведица/ ауı vb.), bazıları da sadece eril cinste (барс, бурсук, кит, носорог, тюлень, морж) ifade edilebilme özelliğine sahiptir. Eğer canlının dişi mi erkek mi olduğu belirtilmek isteniyorsa tıpkı Türkçede olduğu gibi dişi (самka) ve erkek (caмeus) ifadeleri ismin başına getirilmektedir.

Yukarıdaki örneklerden de görüleceği üzere anlamsal açıdan ele alınan sözcüklerin cinslerinin belirlenmesinde bahse konu edilen kişinin (kadın-erkek) cinsinin yanı sıra bu özelliklerin ortaya konmasında sözdizimsel araçların etkisi büyüktür. Bu açıdan dilde bazı kelimelerin hangi cinse ait olduklarını saptamak için, öncelikle sözcüğün kimi karşıladı̆̆ı yani anlamından yola çıkılması, ardından bunun anlaşılır kılınması için sentaks araçlarından faydalanılması gerekmektedir. Bu açıdan anlamsal ve sözdizimsel araçlar sıkı bir ilişki içerisindedir.

\section{Sözcüksel-Türevsel Araçlar}

Son olarak, Rus dilinde kelimelerin cinsleri sözcüksel-türevsel araçlarla ortaya konabilmektedir. Bunda kelime yapımında kullanılan yapım eklerinin büyük bir rolü vardır. Dildeki belirli yapım eklerine bakarak sözcüğün cinsi belirlenebilmektedir. Eril haldeki kelimeye yeni son ekler eklenerek kelimenin eş değerdeki anlamının dişi cinsteki karşılığı

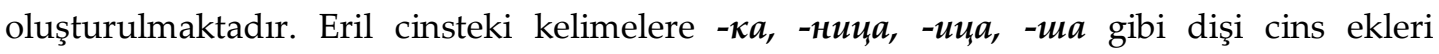
getirilerek dişi cinse ait kelimeler oluşturulmaktadır. Buna göre dilde eril cinse ve dişi cinse ait olan belli başlı isim yapım ekleri tablo 2' de verilmiştir.

Eril cins ekleri

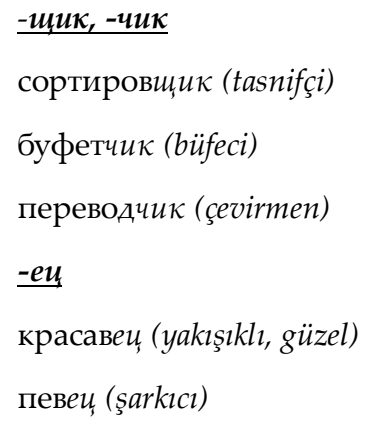

$-e u_{v}-a H u H_{,}-u H$
Dişi cins ekleri

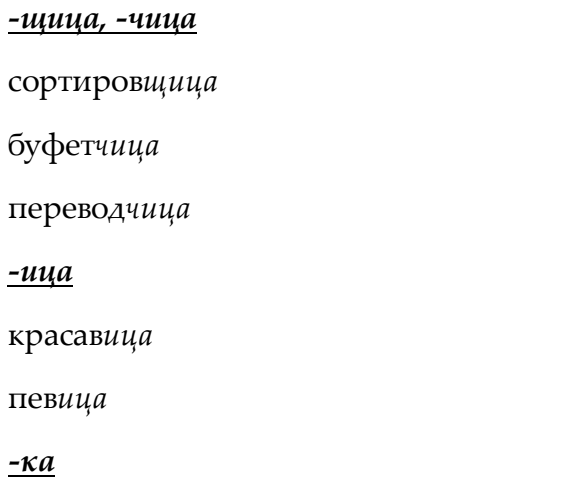




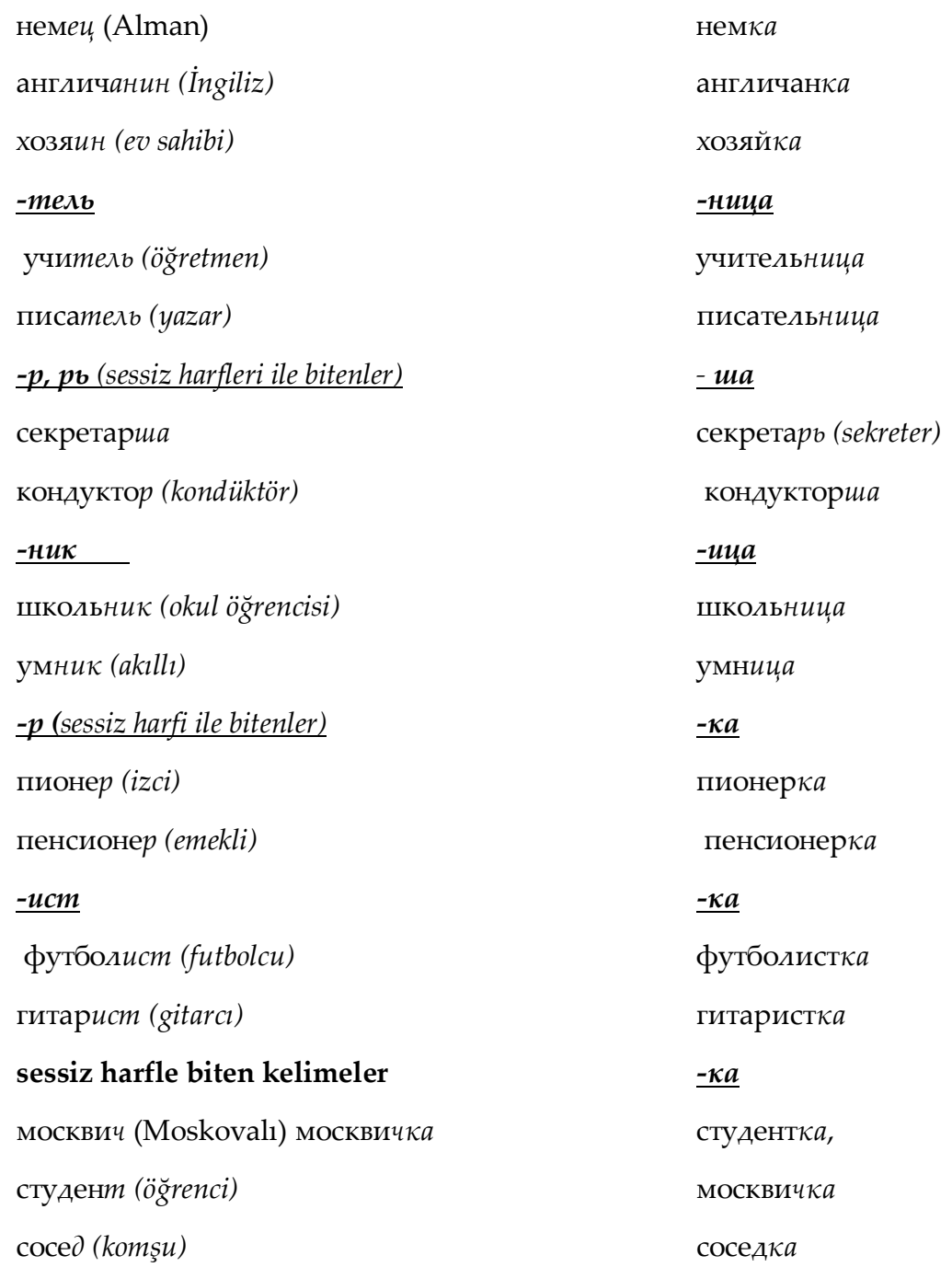

Tablo 2

Görüleceği üzere birçok farklı ek ile eril cinse ait kişi belirten kelimelerin dişi cinsleri oluşturulabilmektedir. Sözcük türetme yoluyla dildeki kelimelerin cinslerini belirlemek için bazı belli başlı son ekler de önemli rol oynamaktadır. Örneğin, dilde sonu -me^vb ve -apb eki ile biten bütün kelimeler (учи-тель, выключа-тель, воспита-тель, слов-арь, календ-арь vb.) eril; dilde sonu -ость ve -есть eki ile biten tüm kelimeler dişi cinse (свеж-есть, тяж-есть, нов-ость, смел-ость) vs.; sonu -ство, -ище ekleriyle biten tüm kelimelerde nötr cinse aittir (строитель-ство, производ-ство, чудов-ище әь.).

Dilde dişil ekler olarak adlandırılan ve dişi cinse ait diğer son ekler ise şu şekildedir: -

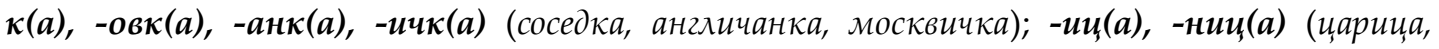
учительница); -их(а), -им(a) (повариха, курьерша); -н(a), -ин(я) (Петровна, цзаревна, героиня); -есс(a), -ис(а) (поэтесса, принцесса, актриса); -ин(a), -ит(а) (балерина, сеньорита); -ух(а) (mолстуха). Bu son ekler sözcüklerin her zaman dişi cinse ait olduklarını bildirerek dildeki dişi cins ayrımını kolaylaştırmaktadır. 


\section{Türkçede Cinsiyet Kavramı}

Rusçanın aksine ise Türkçe, tanımlıklar (Örneğin, Almancadaki gibi der, das, die vs.) ve ekler (Örn. Rusçada $-a,-\Omega,-o,-e$ vb.) gibi belirli dilbilgisi öğelerine sahip olmayan, yapısında dilbilgisel cinsiyeti barındırmayan bir dildir. Türkçede dilbilgisel cinsiyetin bir ekinin olup olmadığı konusunda çeşitli görüşler ileri sürülmüştür. F. Koseaif, A.N. Kononov, Y.V. Şeka gibi Türkologlar Türkçede $-c ̧ a,-m$ gibi dişilik eklerinin (Tanrıça, hanım, kösem, begüm) var olduğunu iddia etmişlerdir (Köseaif 1941: 11, Kononov 1956: 83-85, Şeka 2007: 89-90). C. Kerimoğlu ve G. Doğan, Türkçede dilbilgisel cinsiyetin yabancı dilden alınmış öğelerde görülebileceğini, Türkçeye Batı dillerinden gelen ve -es, -öz ile Slav kökenli -içe eklerinin dişi ekine sahip kelimelerde (prens-prenses, host-hostes, kont-kontes, dansör-dansöz, patron-patroniçe, kral-kraliçe) cinsiyet ayrımını ortaya koymak üzere kullanıldı̆̆ını ifade etmektedirler. Bununla birlikte, F. Braun'un hocanım gibi bir yapıda, hanım sözcüğündeki - anım ekinin Türkçede gelişmekte olan bir dişi cins eki olarak ortaya koyduğu görüşünü aktarmaktadırlar (Kerimoğlu-Doğan 2015: 150-151). Burada değinilen eklerin kısıtlı örneklerde kalması, dilde çeşitlilik arz etmemesi, diğer kelime türetme işlemlerinde kullanılamaması Türkçe için yaygın bir dilbilgisel cinsiyet ekinin var olduğunu söylememize engeldir. Prens-prenses, patron-patroniçe gibi ikili kelimelerde dilbilgisel cinsiyetten çok bir derece sözcüksel ve biyolojik cinsiyetten bahsetmek daha doğru olacaktır. Sözcüksel cinsiyet ve biyolojik cinsiyet uyumlu cinsiyet türleridir ve sözcüklerin anlamlarıyla kısıtlıdır. Sözcüksel cinsiyetle kelime, sözcüğün gerçek dünyada karşıladığı canlının cinsiyetiyle belirlenir. Türkçede sözcüksel cinsiyetin, hayvan adları (tavuk-horoz, inek-öküz, koyun-koç vs.) ve kişilerle (anne-baba, kadın-erkek, anneanne- dede vs.) sınırlı kaldığını görebiliriz. Bunun yanı sıra Türkçede erkekler için erkek, adam, oğlan, bey, bay vb.; kadınlar için kadın, bayan, kız, hanım gibi sözcükler sıfat tamlaması, isim tamlaması, unvan öbeği gibi sözdizimsel yapılarda cinsiyet bildirme aracı olarak kullanılır: erkek/kız öğrenci, kız/oğlan çocuğu, Deniz Bey, Deniz Hanım vs. Hayvanlarda da cinsiyet ayrımını yapabilmek için erkek ve dişi ikilisi kullanılır: erkek köpek, dişi köpek, erkek kuş, dişi kuş vs. Bunun dışında Türkçede, öğretmen, doktor veya mimar gibi meslek isimleri ifade edildiğinde bir ayrım yapmak mümkün değildir. Hitap edilen kişiye göre, öğretmen, doktor veya mimar, kadın da olabilir erkek de. Burada, bu adlandırmanın içeriği, hitap edilen kişiye ve metnin bağlamına göre anlam bulmaktadır. Rusçada da, yukarıda değindiğimiz gibi, benzer bir durum söz konusudur. Çoğunlukla eril cinse ait olan meslek adlarında mesleği icra eden kişinin erkek mi yoksa kadın mı olduğunu belirtirken bu, kişisel adlandırmalar ve kişi cinsiyetlerine göre birer tanım almaktadırlar. Ancak Rusçanın zorluğu, ifade edilen kişiye göre dildeki diğer sözcük türlerinin kullanım ve çekimlerinin belirlenip değişmesinde yatmaktadır. Rusça ile karşılaştırıldığında Türkçenin dilbilgisel cinsiyet açısından Rusçaya oranla fazla bir zorluk teşkil etmediğini görülebilir.

\section{Diğer Zorluklar}

Morfolojik açıdan incelendiğinde, Rus dilinde kelimeler türemiş (yчumь - öğretmek, учитель - ӧ̆̆retmen, учительствовать - ӧ̆̆retmenlik yapmak) türev olmayan (maм - orada, очень - с̧оk, всегда - her zaman) ve birleşik kelimeler (nар-o-ход - buharl gemi, сам-о-критика - öz eleştiri) olmak üzere üç temel grubun ışığında meydana gelmektedir. Bununla birlikte, dilde bazı kelimeler tam olmayan gövdelerden de oluşturulabilmektedir. Kelimenin tam olmayan gövdesinden oluşturulan sözcükler dilde bileşik-kısaltılmış sözcükler (сложносокращенные слова / аббревиатуры) olarak adlandırılmaktadırlar. Çağdaş Rus dilinde kısaltmalar yoluyla oluşturulan birçok kelime bulunmaktadır. Bunların bir kısmı daha çok Ekim Devrimi sonrası meydana gelerek kurum ve kuruluş adlarında sıkça kendini 
göstermeye başlamıştır. Diğer bir kısmı da "dilde ekonomi" kavramı adı altında yer bulmuştur (Martinet 1960: 64-67). Bileşik-kısaltılmış kelimeler dilde genel olarak aşağıda verildiği şekliyle oluşturulmaktadır: 1) Birkaç kelimenin gövde kısmı alınarak: колхоз (коллективное хозяйство - kolektif tarımcllı), райком (районный комитет - bölge komitesi), комсомол (коммунистический союз молодежи - Komünist Gençlik Birliği); 2) Kelimenin sadece baştaki sesleri alınarak: CССР (es-es-es-er - Союз Советских Социалистических Республик - Sovyet Sosyalist Cumhuriyetler Birliği), СНГ (Es-en-ge Страна независимых государств - Bağımsız Devletler Topluluğu Devletleri); 3) Kelimenin sadece baş harfleri kullanılarak: ВУ3 (Высшее Учебное Заведение - Yüksek Öğrenim Kurumu), ТАСС (Телеграфное Агенство Советского Союза - Sovyetler Birliği Telgraf Telefon); МГИМО (Migimo -Московский государственный институт международных отношений - Moskova Devlet Üniversitesi Uluslararası İlişkiler) 4) Birinci kelimenin gövdesi ile ikinci kelimenin tümü alınarak: (завкафедрой (заведующий кафедрой - bölüm başkanı), зарплата (заработная плата - таaş), роддом (родильный дом - doğum evi); 5) Birinci kelimenin başı ile ikinci kelimenin sonu kullanılarak: мопед - (мотоцикд ve велосипед - mореd); 6) Yabancı kökenli bir kelime ile diğer bir kelimenin sonu alınarak: вебинар (веб семинар - internet ortamında gerçekleştirilen seminer).

Bileşik kısaltılmış kelimeler dilde yaygın bir şekilde kullanılmaktadırlar. Bu ve benzeri kelimelerin kullanımında kelimelerin cinsinin belirlenmesinde genel olarak iki yol izlenmektedir. Bunlardan birincisi, eğer kısaltma kelimenin baş harfleri yardımı ile yapılıyorsa, kısaltma içerisinde isim konumundaki kelimeye bakılmaktadır. Örneğin: ВДНХ - Выставка достижений народного хозяйства (Milli Ekonomik Başarılar Fuarı) kısaltmasını deşifre ettiğimizde buradaki ana kelimenin sergi olan "выставка" 'sergi' kelimesine ait olduğunu, kelimenin de dişi cins bir sözcük olduğunu belirleriz. Bu bağlamda ВДHX dişi cinse ait bir kısaltma ifadesi olarak kabul edilmektedir. Yine aynı şekilde $\boldsymbol{P} И \boldsymbol{A}-$ Российское информационное агентство (Rиs haber ajansl) kısaltmasını deşifre ettiğimizde buradaki ana kelimenin nötr cinse ait olan "агентство" 'ajans' sözcüğü olduğunu, böylelikle РИА kısaltmasının nötr cinse ait olduğunu görebiliriz. İkinci yol ise, Rus dilbilimcilerinin de ifade ettiği gibi, sözlüklere başvurulmasıdır. Kısaltma eğer ВУЗ - Высиее Учебное Заведение örneğinde olduğu gibi kelimenin başında yer alan harflerden meydana getirilmişse, kısaltmanın deşifresinde isim halindeki kelime nötr cinse ait olmasına rağmen (bu durumda заведение 'kurum' kelimesi nötr cinse aittir) kısaltmanın başka bir cinse (eril cinse) ait olduğu kabul ediliyorsa sözlüklere başvurulmalıdır (Gvozdev 1973: 149-150; Novikov vd. 2003: 393394). Bu nedenle, ana dili Rusça olanlar için dahi karmaşık bir hal alabilen kısaltma sözcüklerin cinslerinin belirlenmesine tereddütte düşüldüğü anda bu gibi durumlar için özel hazırlanmış olan kısaltmalar sözlügüne bakılması izlenecek en mantıklı yol olarak görülmektedir.

Bunun dışında, dildeki bazı kelimelerin türleri yani cinslerinin varyasyonları bulunmaktadır: манжет (eril cins) - манжета (dişi cins) manşet; банкнот (eril cins) банкнота (dişi cins) banknot; клавиш (eril cins) - клавиша (dişi cins) müzik aleti veya klavye tuşu gibi. Varyasyonlara sahip kelimeler, çă̆daş Rus dilinde eskimiş kullanım olarak kabul edilmektedir. Bunun yanı sıra, benzeri sözcüklerin kullanımlarına edebi eserlerde ya da konuşma dilinde rastlanabildiği gibi Rusçanın çeşitli ağızlarında da görülebilmekte ve bölgesel konuşma özelliklerine göre farklılık gösterebilmektedirler. Günümüz normlarına göre eril cins kabul edilen ancak eskiden dişi cins sayılan "piyano" 'рояль' (dişi cins - eski

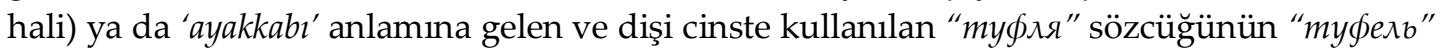
şeklindeki kullanımları buna örnek olarak verilebilir (Novikov vd. 2003: 394, Rozendal 2011: 113).

SEFAD, 2017 (38): 279-298 


\section{SONUÇ}

Rusça kurallı ve sistematik bir şekilde gelişmiş bir dil olmasına rağmen yapısı içerisinde pek çok istisnai durumu ve gramer açısından zorlu oluşumları içerisinde barındırmaktadır.

Dilbilgisel kategoriye ilişkin dildeki istisnai durumlar, bilhassa, 1) hem eril hem de dişi cins olmak üzere her iki cinste de görülebilen yumuşatma işaretine sahip isimleri (mетрадь [defter-dişi], календарь [takvim-erill); 2) cümlede eylemi yerine getiren kişi ya da nesnenin öznesi konumundaki canlı varlıkların eril cinse ait olmasına rağmen, bu cinse ait yabancı kökenli kelimelerin her iki cinsi de gösterebilmeleri (ammame - ataşe, буржуа burjuva) ve diğer sözcük türlerinin çekimlerini etkilemeleri; 3) yabancı kökenli olmamakla birlikte ortak cinse ait olan ve yapısal olarak dişi cinse ait sözcüklerin morfolojik araçlarına sahip sözcüklerin karşıladıkları kişiye göre, kadın ya da erkek, dilde çekime uğramaları (кол^егa - iş arkadaşı, судья - hakim/ hakem); 4) cinsleri karşıladıkları nesneye göre belirlenen ve buna göre diğer sözcük tür çekimlerini etkileyen ad çekim ekimine uğramayan yabancı kökenli cansız varlıkların (манго - mango [nötr veya eril]; авеню - avenue [nötr veya dişi]) kullanım durumlarını kapsar. Cinsi daha çok dilde karşılık geldiği kelimenin anlamından yola çıkılarak belirlenen ve dilde ad çekimine uğramayan yabancı kökenli kelimeler ise, bu kategorinin zorluk derecesini bir adım daha arttırmaktadır. Bu zorluk derecesinin bir ilerisi ise sözcüğün sıfat, zamir, fiil gibi dilin diğer öğelerini etkileyerek onlarla uyum içerisinde olması zorunluluğudur. Bunların yanı sıra, alışılmışın dışında farklı morfolojik araçlarla ifade edilen canlı-cansız yabancı kökenli kelimeler ile dişi cinsin morfolojik araçlarına sahip göstergelerle ifade edilen ancak biyolojik cinsiyet açısından gösterdikleri varlıklar erkek olan sözcüklerin sözdizimsel bütünlüklerinin ortaya konması sırasında da sıkıntılar gözlemlenebilmektedir.

Türkçede dilbilgisel bir kategori olarak mevcut bulunmayan Rusçada ise, karmaşık ve çok kurallı bir sistem şeklinde dilde mevcut bulunan dilbilgisel cinsiyet kategorisi birçok kullanım özelliği ile aslında sadece Rusçayı yabancı bir dil olarak öğrenenler için değil, aynı zamanda o dili konuşanlar için de zorluk teşkil edebilmekte ve ana dili Rusça olan kişilerin de dili kullanımı sırasında dili kişisel tercihlere göre kullandıkları gözlemlenebilmektedir. Örneğin, dişi cinse ait sözcüklere işaret eden -uxa eki, eskiden, alt tabakaya ait kişilerin eşlerini (nовариха [aşı̧ının karısı], пкачиха [dokumacının karısı]), -ua eki ile ifade edilen üst tabakaya ait kişilerin eşlerinden (губернаториа [valinin karısı], генеральша [generalin karısı]) ayırmak için kullanılmaktaydı. Zamanla bu ayrım, kişiler arasında dişi ve eril ayrımı yapılmak için kullanılmıştır: врач (doktor - eril) - врачиха (doktor - dişi), ceкpemaps (sekreter eril) - секретариа (sekreter - dişi), nовар (aşçı-eril) -nовариха (aşç - dişi) gibi. Zamanla değiş̧en ve gelişen dil ile birlikte, bu sözcüklerin kullanım alanları da değişmeye başlamıştır. Dildeki hemen hemen tüm meslek adları eril cinse ait kabul edilmiş, yukarıda bahsedilen eklerin dişi cinse yönelik kullanımlarının ise (врачиха, профессориа) olumsuz bir çağrışımı barındıran, ifade edildiğinde hor görme anlamlarını kazanan kelimeler olarak belirlenmiştir (Rozendal 2011: 120-121). Resmi dilde ve yazışmalarda sekreter, doktor, muhasebeci, profesör gibi meslek adları her zaman eril cinste kullanılmaktadır. Ancak günlük konuşma dilinde, olumsuz çağrışım barındırdığı dile getirilen sözcüklere anadili konuşucularının ifadelerinde rastlanabilmektedir. Bu ve benzeri kelimelerin kullanımları tercih meselesi olarak ortaya çıkmaktadır. Bu da ele alınan bu konunun dilin kendi yapısı içerisinde öğrenilmesi ve benimsenmesinin dahi oldukça zorlu olduğunu göstermektedir. 
Özetle, varlıkların üç farklı cinse ait olmalarının yanında canlı veya cansız varlıklar olarak sınıflandırılmaları ve bunların kelime çekimlerine yansımaları, dilbilgisel cinsiyetin morfolojik, sözdizimsel, anlamsal ve türevsel açlardan çeşitlilik göstermesi, kelimelerin cinslerinin morfolojik olarak her zaman üç cinsin sahip olduğu çekim eklerinden yola çıkarak belirlenememesi ya da 'nymo' (yol) benzeri eril cinse ait kelimelerin dişi cins gibi çekime uğraması gibi istisnai durumlar, dildeki cinsiyet kategorisinin ve başlı başına Rusçanın bir yabancı dil olarak öğrenimindeki temel zorlukları oluşturmaktadır. Tüm bu istisnai durumlar ve kullanım zorlukları Rusçayı yabancı bir dil olarak öğrenen Türk öğrencileri için dilin bu kategorisini anlamayı ve kullanmayı güçleştirmekte ve bu kategoriye yönelik sistemsel bir paradigmanın oluşturulmasını zorlaştırmaktadır. Buna karşılık, Rus dilinin cinsiyet kategorisinin içerisinde barındırdığı tüm bu çeşitliliğe rağmen bu yapı, sıfat, zamir, sayı ve fiil çekimleriyle kendi içerisinde bir düzene sahiptir. Belirli bir sistem içerisinde gelişim göstermiş olan dilin cinsiyet kategorisine ilişkin temel kurallarının bilinmesi, bu kategorinin öğretilmesinde sistematik olarak belirli bir düzen içerisinde ilerlenmesi, söz konu karmaşık yapının öğreniminde yaşanacak zorluklar ile kullanımında yapılacak yanlışların en aza indirgenmesinde yardımcı rol oynayacaktır.

Buna göre, yabancı dil olarak Rusçayı öğrenen Türk öğrencilerin Rusça eğitimi sürecinde Rusçadaki cinsiyet kategorisini benimsemelerine yardımcı olacak birkaç temel metot sıralanabilir:

1) Rusçada sonu yumuşatma işareti ile biten eril ve dişi cinslere ait sözcüklerin öğretimi, tıpkı Almancadaki cinsiyet kategorisinde eril (der) ve dişi (die) cinslere ait kelimelerin sahip olduğu artikellerle beraber öğretildiği gibi, sözcüğün kendisinden önce gelebilecek ismi niteleyip belirli kılacak sıfat veya zamir gibi bir belirteçle verilerek gerçekleştirilebilir: красная площадь, прекрасная жизнь, моя любовь, чёрный портфель, большой корабль, русский словарь vb. Söz konusu yöntemle sözcükler arası kelime ilişkisi sayesinde öğrencinin içgüdüsel bir çağrışımla kelimeyi hatırlaması daha kolay olabilecektir.

2) Yine sonu yumuşatma işareti ile biten kelimelerin öğrencinin hafızasına iyice kazınabilmesi için, öğrencinin hafızası görsel materyaller ve alıştırmalarla desteklenmelidir. Buna yönelik olarak kadın ve erkek figürlerinin yer alacağ materyaller oluşturulabilir ya da dişi ve erkek cinse atfedilen mavi ve pembe renkteki kartonların üstüne, sonunda yumuşatma işareti olan sözcükler yazılarak çeşitli oyun teknikleri ile öğrencinin öğrenim becerileri arttırılabilir.

3) Sonu dişi cinse ait gramer araçlarına sahip (-a/-r) eril cinse ait sözcüklerin aktarımı zamir ya da sıfatlarla birlikte sunularak gerçekleştirilmelidir. Sözcüğün önünde bir belirleyici bulunması, hem çekim sırasında dişi cinse ait çekim özellikleri ile benzeri özellik gösteren kelimelerin çekimlerinin karışmamasını sağlayacak, hem de sözcüklerin ait oldukları cinsiyet kategorisinin doğru hatırlanmasını sağlayacaktır: мой папа, наш дедущка, красивый юноша vb.

4) Калека, обжора, сирота gibi ortak cinse ait kelimelerin öğretilmesinde ise ortak cins olarak adlandırılan kategoriye sahip dildeki sözcüklerin sınıflandırması yapıldıktan ve cinsiyet kullanımlarının bahse konu kişiye göre şekil bulduğunun açıklanmasından 
sonra, bunlarin a) sifat (бедный-бедная сирота, маленький калека-маленькая калека) b) işaret zamiri “такой” (Он такой обжора! / Она такая обжора! / Вы такого забияку еще не видели!/ вы такую забияку еще не видели!) ve c) dilde pronominal sıfat, bağlaç ya da soru sözcüğ̈̈ olarak kullanılabilen, şaşkınlık, hayranlık, sevinç belirten "какой" (какой он подлиза! / какая она подлиза!) sözcükleri ile birlikte çoğunlukla ünlem ifadesine sahip cümlelerde kullanıldıkları açıklanabilir.

5) Yabancı kökenli sözcüklerin kullanımında ise işaret ettikleri varlıklara göre sinıflandırma yoluna giderek sistematik bir materyal sunumu, yaşanabilecek kafa karışıklığını ortadan kaldıracaktır. Yabancı dillerden Rusçaya geçen ve dişi cinse ait varlıkları ifade eden sözcüklerin sondaki gramer araçlarına bakılmaksınız (фpay, леди) dişi cinse; eril cinse ait varlıkları ifade eden sözcüklerin yine sözcüğün sonunda sahip olduğu gramer aracına bakılmaksızın (месьё, месье, мосье) eril cinse ait oldukları aktarılmalıdır. Sonunda farklı gramer araçlarına sahip meslek adlarını ya da belirli bir sınıfı belirtmek için kullanılan kelimelerin (маэстро, атташе, буржуа) ise yine işaret ettikleri kişiye göre ifadede cinsiyetinin belirlendiğinin altı çizilmelidir. Yine çeşitli yabancı kelimelerin gramer araçlarına bakılmaksınız karşıladıkları varlıklarla öğretilmesi ve yardımcı belirleyicin de kullanımıyla sunulmaları yabancı kökenli sözcüklerin sahip oldukları dilbilgisel cinsiyetin belirlenmesinde kolaylık sağlayacaktır. Yabancı dilden Rusçaya geçen kelimelerin cinsiyetleri konusunun cinsiyet kategorisi içerisinde en son sırada öğrenciye verilmesi bu kategoriye ait tüm parçaların iyice oturmasına yardımcı olacaktır. Kelimenin cinsini belirlemekten ziyade sözcüğün anlamını ortaya koyacak olan ve böylece ifadenin cinsinin belirlenmesine yardımcı olacak sözlük çalışmalarının yapılması gerekmektedir.

Eğitim sürecinde yukarıda sayılan noktaların yanı sıra, doğru kaynak seçimi ve alan çalışmasını kapsayan sözlüklerin kullanımı, bu kaynaklardaki bilgilerin sistematik ve düzenli bir şekilde öğrencilere sunulması eğitim sürecine olumlu katkı sağlayacak araçlar olarak karşımıza çıkmaktadır. 


\section{SUMMARY}

Students may experience many difficulties during language learning. One of these difficulties is the grammatical gender category in the Russian language, which contains excessive use of exclusivity. The concept of gender in the language is a category that separates nouns into classes and requires a relationship of harmony among words that are used together. The gender category, which acts as a grammatical category in Russian, affects all parts of the language, especially number, adjectives, and pronoun conjugations. Almost all singular words in Russian have three potential forms, corresponding to each of the three genders (masculine, feminine and neuter). In the Russian language, various instruments are used during the expression of the gender category. We can categorize these tools in four main groups. These are morphological, syntactic, lexical-semantic and lexical-word derivation tools. Morphological tools include the usage of morphemes within the framework of certain rules. Syntactic tools specify the type of words which are expressed by nouns, according to a morpheme or suffix located at the end of the word. Lexical-semantic tools help to understand the meaning of words according to their lexical definition. Finally, lexical-word derivation tools help to specify the gender of the word according to the nounmaking suffixes they have.

The aim of the study is three-fold: first, to show the difficulties encountered by Turkish students learning Russian as a foreign language during the acquisiton of the grammatical gender category, which has an important place in the process of mastering the Russian language; second, to draw attention to the development of possible educational methods regarding this subject; and third, to determine if any systematic method can be created. Challenges related to learning the gender category in Russian include the following difficulties: 1) Softening signs are used, which can be seen in masculine and feminine words (mетрадь [notebook-feminine], календарь[calendar-masculine]); 2) Words of foreign origin can show both genders (ammame - attache, буржуа - bourgeois); 3) Words which are in the class of «common nouns» and which structurally have morohological tools of feminine gender can be declined according to the feminine declension, depending on whether a male or female is being talked about. (кол^егa - iş arkadaşı, cyдıs - judge / arbitrator); 4) İnanimate objects (words) which have a foreign origin and are non-inflected for case. The gender of these words is determined by the object they mean in language (манго - mango [neuter or masculine]; авеню - avenue [neuter or feminine]). This increases the difficulty level of this category one step further. Beyond this level of difficulty is the further grammatical requirement that the word that has to be in harmony with the other elements of language such as adjectives, pronouns and verbs. Besides these, difficulties are also observed during the presentation of the syntactic integrity of words including animate and inanimate nouns that come from foreign origin (кенгугу, интервью) as well as words which are expressed by the morphological means of the feminine gender but biologically are actually male (папа, дядя, юноша).

In brief, the following facts constitute the main difficulties in learning the gender category and thus learning Russian as a foreign language. 1) words in Russian have three genders and 2) they classify as animate-inanimate objects, 3) all of these facts affect noun declension, 4) the diversity of grammatical gender forms morphological, syntactic, lexical- 
semantic and lexical-word derivative aspects, 5) the gender of the words cannot always be determined from the suffixes of the three genders, and 6) expectional circumstances exist such as words like'путь' (way), which has the masculine gender but inflects as does the feminine gender.

All the expectional situations and difficulties in the usage of this category make it difficult to grasp for the Turkish students who learn Russian as a foreign language, and who have no grammatical gender category in their own language. They (the expectional usages of the gender category) also make it difficult to establish a systematic paradigm for this category. On the other hand, despite all the diversity that the Russian language has in the gender category, we can mention that this structure presents a plan in and of itself with its adjective, pronoun, number and verb conjugations. Knowing the basic rules of this language's gender category, which has developed in a certain system, following a systematic teaching of this category in a certain order will play a helpful role in minimizing the difficulties in learning this complex structure and reducing most of the mistakes made in its use.

There are a few basic methods that can help Turkish students who learn Russian as a foreign language to grasp the Russian gender category during the education process of Russian language. According to this:

1) Teaching the masculine and feminine words ending with a soft sign can be carried out by using an adjective, which will come before the word and will specify the gender of the word: краснал площадь, прекраснал жизнь, моя любовь, чёрный портфель, большой корабль, русский словарь etc. While explaining the usage of the words, ending with soft sign, their application together with adjectives or pronouns will help students to memorize these words much easier.

2) In order to help the students to keep the words, ending with soft sign, in their mind, it is advisable to support the lesson with usage of visual materials and exercises. For this purpose we can use the pictures of male and female. At the same time to increase the learning ability of the students the words with soft ending can be written on blue or pink cards, which are attributed to male and female gender. In this way, learning skills of the students can be enhanced with various playing techniques.

3) The masculine words with the female grammar means (-a/-я) can be presented together with pronouns or adjectives: мой папа, наш дедушка, красивый юноша etc.

4) In the process of teaching common gender of the words, after classification of these words and explanation that the gender of these words depends on the person, about whom we are talking at that moment, it would be beneficial to show how these words can be used with adjectives (бедный-бедная сирота, маленький калекамаленькая калека), with demonstrative pronoun "такой" (Он такой обжора! / Она такая обжора! / Вы такого забияку еще не видели!/ вы такую забияку еще не видели!) 
and with "какой" which can be used as a conjunctive, question word in language or which signifies amazement, admiration and pleasure (какой он подлиза! / какал она подлиза!)

5) While using the foreign origin words it should be mentioned that their usage also depends on the person, about whom we are talking at that moment, and it is not necessary to pay attention to the grammar means, which these words have (fpay, леди, атташе, буржуа). The gender of the foreign words in Russian language should be taught after all other categories of the nouns have been explained.

Prior to the definition of the word's gender, it is recommended to work with dictionary, which helps to define not only the word's meaning, but its gender as well. 


\section{KAYNAKÇA}

ATLI, Mehmet Halit (2013). "Almancada Dilbilgisel Cinsiyet Sistemi ve Bu Sistemin Yabanc1 Dil Olarak Edinimi". Dil Dergisi (160): 5-25.

DOĞAN, Aksan (2015). Her Yönüyle Dil Ana Çizgileriyle Dilbilim. Ankara: Türk Dil Kurumu Yay.

GVOZDEV, Aleksandr (1973). Sovremennıy ruskiy literaturnıy yazık, çast I, fonetika i mofrologiya. Moskva: 146-163.

KERIMOĞLU, Caner-DOĞAN, Gökçe (2015). “Türkçede Cinsiyet Görünümleri ve Çağrışımsal Zihniyet". Türklük Bilimi Araştırmaları Dergisi XXXVIII: 143-178.

KONONOV, Andrey (1956). Grammatika turetskogo yazıka. Moskva: Akademiya nauk SSSR.

KÖSEAİF, Fuat (1941). “-Çe -Ça eki dişilik eki midir?". Çınaraltı dergisi (13): 11.

KUZMINA, Natalia (2010). Russkaya grammatika v tablitsah . Moskova: Flinta: 28.

MARTINNET, Andre (1960). Printsipı ekonomii v fonetiçeskih izmeneniyah. Moskva, izd. İnost. lit.

MILANOVA, İrina (2011). Russian grammar / translated by Polishchuk E.V. - Moskow: Living Language: 12 .

NOVIKOV, Lev vd. (2003). Sovremennıy russkiy yazık, Uçebnik. Fonetika, Leksikolojiya, Solovoobrazovanie, Morfolojiya, Sintaksis. St. Peterburg: İzd. Lan: 388-395.

ÖZTÜRK DAĞABAKAN, Fatma (2011). “Dillerde Cinsiyet: Almanca ve Türkçede Cinsiyet Kavramları". A.Ü. Türkiyat Araştırmaları Enstitüsü Dergisi (46): 281-300.

RAMAZANOVA, Shalala-ÇETINKAYA, Ersin vd. (2016). Rusça-Türkçe Yumuşatma İşaretiyle Biten İsim Sözlüğü. Kayseri: Orka Matbaa.

ROZENDAL, Emanuel (2011). Spravoçnik po russkomu yazıku. Praktiçeskaya Stilistika. Moskova: İzd. Astrel.

RUSSKIY ORGOGRAFIÇESKIY SLOVAR (ROS) (2002). ed. V.V. Lopatin. http://www.dict.t-mm.ru/lopatin/k/kof.html [13.05.2016].

ŞAKAR, Reşat (2014). “Rus Dilbiliminde Biyolojik Cinsiyetin Fonksiyonel-Semantik Alanının Sözcüksel ve Dilbilgisel Karşılaştırması". The Journal of Academic Social Science Studies. International Journal of Social Science (29): 485-497.

ŞEKA, Yuri (2007). Praktiçeskaya grammatika turetskogo yazıka. Moskova: Ast-Vostok-Zapad.

UZUN, Nadir Engin (2004). “Dünya Dillerinden Örnekleriyle Dilbilgisinin Temel Kavramları Türkçe Üzerine Tartışmalar". Türk Dilleri Araştırmaları Dizisi 39. İstanbul: 110-119. 